

\title{
2. Sınıf Türkçe Ders Kitabındaki Metinlerle Çalışma Kitaplarındaki Etkinliklerin Söz Varlığı Açısından Karşılaştırılması Bayram BAŞ \\ Serpil Demirci** \\ Özet
}

Genelde söz varlığı unsurları, özelde kelime öğretimi öğrencinin dil becerilerinin desteklenmesi konusunun önemli bir basamağını oluşturmaktadır. Sınıf seviyelerine uygun kelime listelerinin titizlikle oluşturulup ders ve çalışma kitapları için hazırlanan etkinliklerde kullanılması öğrencilerin ortak bir kelime hazinesine sahip olması açısından önemlidir. Bu sebeple hazırlanan ders ve çalışma kitabındaki kelimeler birbiri ile uyumlu olmalıdır. Kelime listelerinden hareketle düzenlenen etkinliklerin nitelikli olması ve öğrencide kelime farkındalığı oluşturması beklenmelidir. Öğrenci kelime ezberlemek yerine kelime anlamı öğrenme stratejisini kavramalı ve bu yeteneğini hayat boyu kullanmalıdır. Bu düşünceden hareketle çalışmada, illkokul 2. sınıf Türkçe Ders Kitabı metinleri ve Türkçe Çalışma Kitabı etkinliklerinde kullanılan hedef söz varlığı unsurlarının birbiri ile ne oranda örtüştüğü saptanmış ve var olan uygulama betimlenmiştir. Ders ve etkinlik kitabındaki hedef söz varlığı unsurları nitel araştırma kapsamında doküman incelemesi yöntemi ile karşılaştırılmış ve ders ve çalışma kitabında yer alan söz varlığı unsurları içinde yalnızca 161 kelimenin ortak olduğu tespit edilmiştir

Anahtar kelimeler: Türkçe ders ve öğrenci çalışma kitabı, söz varlığı unsurları, kelime farkındalığı, kelime öğretimi

\section{The Comparison of the Texts in the 2 nd Grade Turkish Textbook with the Activities in the Workbooks in Terms of Vocabulary Abstract}

In a broad sense, vocabulary elements and in a narrow sense, vocabulary teaching form an important basis for supporting the language skills of the students. Forming an ideal vocabulary list meticulously and using it in the activities of the textbooks and the workbooks are important for students to have a mutual vocabulary. Therefore, the vocabulary in the textbooks and the workbooks needs to comply with each other. Based on the vocabulary list, It is expected that the activities should be qualified and create vocabulary awareness. Instead of memorizing, the students should comprehend the vocabulary learning strategies and use this skill for lifetime. Based on this idea, at what rate the target vocabulary elements in Turkish textbooks and workbooks are compatible with each other is determined and the existing practice is described. The target vocabulary elements in the textbooks and the workbooks are compared within the context of qualitative research by means of the document review method. It is determined that 161 words are mutual out of the vocabulary elements in the textbook and the workbook.

Key words: Turkish Textbook and Workbook, Vocabulary Elements, Vocabulary Awareness, Vocabulary Teaching.

\footnotetext{
* Doç. Dr., Yıldız Teknik Üniversitesi, Eğitim Fakültesi,Türkçe Eğitimi Bölümü. e-posta: bayrambas@gmail.com

** İstanbul Aydın Üniversitesi, Sosyal Bilimler Enstitüsü, Yüksek Lisans Öğrencisi.

e-posta: serpil_demirci@hotmail.com
} 


\section{Giriş}

"Kelime bilgisi mühimdir. Amerikalı filozof ve maarif̧̧i Dr. John Dewey, bu durumu "Kelimesiz düşünmek imkânsızdır." sözleriyle belirtir. Yine dil bilgini Norman Lewis ise "Kelime bilginizin hududu zekânızın hududunu tespit eder. Kelime bilginiz arttıkça zekânız da artacaktır." ifadesini kullanır" (Özdoğru, 1958: 9). İnsanın sahip olduğu kelime bilgisi günlük yaşamda karakterini ve bakış açısını yansıtan en önemli göstergelerden biridir. Konuşurken ya da yazarken seçtiğimiz kelimeler ile düşüncelerimizi ve dolayısıyla kendimizi ifade ederiz. Kelime bilgimizi arttırarak kelime hazinemizi de arttırmış oluruz. "Kelime hazinesi, bildiğimiz kelimeleri ifade etmektedir. Öğrencinin kelime hazinesini zenginleştirmek, bildiği kelimelerin sayısını artırmak anlamına gelmektedir. Herhangi bir kelimeyi bilmek, o kelimeyi doğru seslendirmek, doğru yazmak; konuşurken ve yazarken yerinde kullanmak; okuduğunda ya da duyduğunda da ne ifade ettiğini anlamak demektir" (Onan,2013:155).

Türkçe Sözlük'te kelime hazinesi ve söz varlığı aynı anlamda verilmektedir (TDK,2005). Fakat söz varlığı yalnızca kelimelerden ibaret değildir. Karadağ (2013:8), söz varlığını "Söz kavramının genişliği içinde dilde kelime ve kelime üstü birimler olan ikileme, deyim, atasözü vb. anlamlı dil birimlerinin oluşturduğu birikimin bütünüdür" şeklinde tanımlamaktadır. Öğrencilerin kelime hazinelerinin ve söz varlığının geliştirilmesi hususu, İlköğretim Türkçe Dersi Öğretim Programı (1-5.Sınıflar)'nda, "Metinler arası okuma becerilerini geliştirerek söz varlığını zenginleştirmek" (MEB, 2009: 12) ifadesi ile İlköğretim Türkçe Dersi Öğretim Programı (6, 7, 8. Sınıflar)'nda “Okuduğu, dinlediği ve izlediğinden hareketle, söz varlığını zenginleştirerek dil zevki ve bilincine ulaşmaları; duygu, düşünce ve hayal dünyalarını geliştirmek" (MEB,2006:4) ifadesi ile genel amaçlar arasına alınmıştır. Bu amaçlar söz varlığının önemini vurgulamakta ve öğrencilerin söz varlığının ders kitapları aracılığıyla da geliştirilmesi gerektiğini ortaya koymaktadır.

“Öğrencilerin kelime hazinesi farklı kanallardan beslenmektedir. Aile çevresi, arkadaş çevresi, öğretmen/öğretmenler, iletişim araçları ve her türlü okuma materyali kelime hazinesine etki etmektedir" (Karadağ ve Kurudayıoğlu, 2005:3). Türkçe ders ve çalışma kitapları bu kanallardan biri olan okuma materyallerinin başında gelmektedir. Öğrenciler, kelime öğretimiyle en yoğun çalışma kitabı etkinliklerinde karşılaşmaktadır. Kelime öğretimi kapsamında öğrencilerin etkinliklerde yeni kelimelerle karşılaşması, dil becerilerinin geliştirilmesi açısından da önemlidir. Baş(2006:5) “Çocuğun dil gelişiminde, kelime ediniminin çok önemli bir yeri vardır. Dinleme ve okuma becerilerini kullanan çocuk, alıcı kelime hazinesine dâhil ettiği yeni kelimeleri, üretici kelime hazinesine, bu kanalla da konuşma ve yazma becerilerine transfer etmektedir." ifadesi ile öğrenilecek yeni kelimelerin öğrencilerin dil becerilerinin geliştirilmesine katkısını vurgulamaktadır. 
2. Sınıf Türkçe Ders Kitabındaki Metinlerle Çalışma Kitaplarındaki Etkinliklerin Söz Varlığı Açısından Karşılaştırılması

Öğrencilerin söz varlığını geliştirmek amacıyla hazırlanan ders kitaplarında yer alan etkinliklerin uygulayıcısı öğretmenlerdir. Öğretmenlerimizin, söz varlığı unsurlarından hareketle planlama yapmaları, bu yönde güdümlü etkinlikler hazırlamaları ve bunları uygulamaya geçirmeleri oldukça önemlidir. Çoğu zaman öğrenciler Türkçe derslerinde karşılaştıkları etkinliklerde söz varlığı unsurlarını öğrenmek yerine onları algılamadan üstünkörü okumalar gerçekleştirmektedir. Bu durum, anlamsız öğrenmelere yol açabilmektedir. Öğrencinin üretici kelime hazinesinin gelişememesinin sebeplerinden biri de öğrencilerin karşılaştığı söz varlığı unsurlarını algılayamaması ve onlarla geçici olarak etkileşmesidir. Öğretmenler, etkinliklerin uygulayıcısı olarak bu olumsuzluğu ortadan kaldırmada önemli bir role sahiptir. Bu rol gereği öğretmenler, mevcut etkinliklerde yeni karşılaşılan söz varlığı unsurlarına dikkat çekerek öğrencilerin bu unsurları ne kadar fark ettiğinin ve öğrendiğinin nabzını tutmalıdır. Öğretmenlerimizin etkinliklerde tüm söz varlığı unsurlarını (kelime, ikileme, deyimler, atasözleri vb.) işe koşması ve öğrencilerin kelime farkındalı̆ını arttırması, kelime öğretim sürecini dinamik hâle getirecektir.

Söz varlığı öğretimi açııından en önde materyaller arasında olan ders kitapları ve öğrenci çalışma kitaplarının ortaklığı ve uyumluluğu da dikkat edilmesi gereken önemli bir husustur. Çünkü öğrencinin ders kitaplarında yer alan metinlerde karşılaştığı bir söz varlığı unsurunu, çalışma kitabındaki etkinliklerde de görmesi ve yeni edindiği bu unsurla ilgili çeşitli çalışmalar yapması, alıcı ve üretici söz varlığının gelişmesi açısından son derece önemlidir. "Söz varlığı alıcı ve üretici söz varlığı olmak üzere ikiye ayrılır. Dinleme ve okuma söz varlığının alıc yanıyla, konuşma ve yazma üretici yanıyla gerçekleşir" (Karadağ ve Maden, 2010:272). Bu doğrultuda çalışmanın amacı, İlkokul 2. sınıf Türkçe Ders Kitabı metinleri ve Türkçe Çalışma Kitabı etkinliklerinde kullanılan söz varlığı unsurlarının örtüşme oranlarını tespit etmek ve bu yönde değerlendirmeler yapmaktır.

Araştırmanın amacına ulaşmak için aşağıdaki sorulara cevaplar aranmıştır:

1. İlkokul 2. Sınıf Türkçe Ders ve Öğrenci Çalışma Kitabı'nda yer alan etkinliklerden hangileri kelime öğretimi ile ilgilidir?

2. Illkokul 2. Sınıf Türkçe Ders ve Öğrenci Çalışma Kitabı’nda bulunan kelimeler nasıl bir dağılım göstermektedir?

3. İlkokul 2. Sınıf Türkçe Ders ve Öğrenci Çalışma Kitabı’nda bulunan kelimeler ne sıklıkla tekrar etmektedir?

4. Illkokul 2. Sınıf Türkçe Ders ve Öğrenci Çalışma Kitabı'nda hangi söz varlığı unsurlarına rastlanmaktadır?

5. İlkokul 2. Sınıf Türkçe Ders ve Öğrenci Çalışma Kitabı'nda bulunan metinler ve etkinliklerde örtüşen söz varlığı unsurları nelerdir? 


\section{Yöntem}

Araştırma, nitel araştırma yaklaşımı kapsamında betimsel tarama modeline uygun doküman incelemesi yöntemi ile gerçekleşmiştir. Doküman incelemesi, araştırılması beklenen olgu veya olgular hakkında bilgi içeren yazılı materyallerin analizini kapsar. Nitel araştırmada doküman incelemesi tek başına bir veri toplama yöntemi olabileceği gibi diğer veri toplama yöntemleri ile birlikte de kullanılabilir (Yıldırım \& Şimşek, 2013:217).

\section{Araştırmanın İnceleme Nesneleri}

Araştırmada, 2014-2015 eğitim-öğretim yılında ilkokul 2. sınıflarda okutulan ve Bilim Kültür Yayınları tarafından yayımlanan İlkokul 2. Sınıf Türkçe Ders ve Öğrenci Çalışma Kitabı incelenmiştir.

Ders kitabındaki söz varlığı unsurları, kitapta bulunan toplam 48 adet okuma ve dinleme metninden elde edilmiştir. Türkçe 2. Sınıf Çalışma Kitabı'nda metin işleme sürecinin 19 farklı aşamasında toplam 252 etkinlik bulunmaktadır. Çalışma kitabındaki “Anahtar Kelimelerle Çalışma (20), Görsel Okuma (5), Anlamı Bilinmeyen Kelimelerle Çalışma (4), Söz Varlığını Geliştirme (21), Söz Varlığını Kullanma (9) ve Ölçme ve Değerlendirme (1)" aşamalarında, kelime öğretimine yönelik toplam 60 etkinlik yer almaktadır. Çalışma kitabındaki söz varlığı unsurları bu etkinliklerden elde edilmiştir.

Ders kitabındaki tüm okuma ve dinleme metinlerinin ve çalışma kitabında doğrudan kelime öğretimine yönelik olarak verilen etkinliklerin söz varlığı unsurları açısından değerlendirilmesi, araştırmanın geçerlik ve güvenirliğini artırmaktadır.

\section{Verilerin Analizi}

Metinlerde ve etkinliklerde yer alan söz varlığı unsurları (kelime, ikileme, deyim, atasözü) ayrı ayrı bilgisayar ortamına aktarılmış ve "Simple Concordance Program 4.0.7" ve "Microsoft Excel" programları kullanılarak analiz edilip listelenmiştir.

Ders kitabındaki söz varlığı unsurları belirlendikten sonra çalışma kitabı ile örtüşen söz varlığı unsurlarını (kelime, ikileme, deyim, atasözü) tespit etmek amacıyla çalışma kitabında bulunan etkinlikler analiz edilmiştir. Ders kitabı ve çalışma kitabındaki söz varlığı unsurları karşılaştırılmış ve ortak unsurlar tespit edilmiştir.

\section{Bulgular ve Yorum}

Bu bölümde ders kitabı ve çalışma kitabında bulunan söz varlığı unsurlarından kelime, ikileme, deyim ve atasözleri değerlendirmeye alınmıştır.

\section{Kelimelere Yönelik Bulgular ve Yorum}

Ders ve çalışma kitabında yer alan kelimelere dair nicel veriler aşağıdaki tabloda gösterilmiştir: 
2. Sınıf Türkçe Ders Kitabındaki Metinlerle Çalışma Kitaplarındaki Etkinliklerin Söz Varlığı Açısından Karşılaştırılması

Tablo: 1 Ders ve Çalışma Kitabında Bulunan Kelimeler

\begin{tabular}{|c|c|c|c|}
\hline Kitaplar & Toplam Kelime & Farklı Kelime & TK/FK \\
\hline Ders Kitabı & 7449 & 1826 & 4,07 \\
\hline Çalışma Kitabı & 238 & 210 & 1,13 \\
\hline
\end{tabular}

Ders kitabındaki metinlerde öğrenciler toplam 7449 kelime ile karşılaşmaktadır. Bu kelimeler 1826 farklı kelimenin (Ek-1) 4,07 oranında tekrarlanmasıyla oluşmuştur. Çalışma kitabında ise öğrenciler toplam 238 kelime ile karşılaşmaktadır. Bu kelimeler ise 210 farklı kelimenin (Ek-2) yaklaşık 1,13 oranında tekrar edilmesiyle oluşmuştur.

Ayrıca çalışma kitabında yer alan kelimelerin bazıları görsel öge olarak verilmiştir. Çalışma kitabında görsel olarak verilen 73 farklı kelime (*ay, *türkçe çalışma kitabı, *türkçe ders kitabı, al, armut, atlıkarınca, ayva, baca, basketbol, biber, bot, bülbül, ceket, çanta, çarpışan araba, çizme, çoban, çorap, dal, dikdörtgen, dönme dolap, elma, endişeli, fıçı, fidan, futbol, gövde, gül, güneşli, güreş, incir, kalem, kalemtıraş, kar yağışı, kaşık, kayısı, kazak, kazma, kırmızı, kiraz, koyun, kök, kurt, kürek, limon, lokomotif, masa tenisi, mavi, mutlu, muz, palto, parçalı bulutlu, pasta, pembe, portakal, sağanak yağışlı, salıncak, sarı, silgi, sümbül, şaşkın, tren, turuncu, tuzluk, uçkurluk, üzüm, vagon, voleybol, yağmurlu, yaprak, yeşil, yıldız, yüzme ) görsellerin adı sorulmak suretiyle kelime öğretimi etkinliklerinde yerini almıştır.

\section{ikilemelere Yönelik Bulgular ve Yorum}

Ders ve çalışma kitabında yer alan ikilemelere dair nicel veriler aşağıdaki tabloda gösterilmiştir:

Tablo: 2 Ders ve Çalışma Kitabında Bulunan Ikilemeler

\begin{tabular}{|c|c|c|c|}
\hline Kitaplar & Toplam İkileme & Farklı İkileme & Ti/Fi \\
\hline Ders Kitabı & 56 & 45 & 1,24 \\
\hline Çalışma Kitabı & - & - & - \\
\hline
\end{tabular}

Ders kitabı metinlerinde toplam 56 ikileme yer almaktadır. Bu ikilemeler 45 farklı ikilemenin (Ek-3) 1,24 oranında tekrar etmesiyle oluşmuştur. Çalışma kitabında ise ikilemelere yer verilmediği görülmektedir.

\section{Deyimler ve Atasözlerine Yönelik Bulgular ve Yorum}

Ders ve çalışma kitabında yer alan deyim ve atasözlerine dair nicel veriler aşağıdaki tabloda gösterilmiştir: 
Tablo: 3 Ders ve Çalışma Kitabında Bulunan Deyim ve Atasözleri

\begin{tabular}{|c|c|c|c|c|}
\hline Kitaplar & Toplam Deyim & Farklı Deyim & TD/FD & Atasözleri \\
\hline Ders Kitabı & 64 & 57 & 1,12 & - \\
\hline Çalışma Kitabı & 1 & 1 & 1 & - \\
\hline
\end{tabular}

Ders kitabı metinlerinde toplam 64 deyim kullanılmıştır. Bu deyimler 57 farklı deyimin (Ek-4) 1,12 oranında tekrar edilmesiyle oluşmuştur. Çalışma kitabında ise sadece 1 deyime (gözlerini açmak) yer verilmiştir. Ders kitabı metinleri ve çalışma kitabı etkinliklerinde atasözlerine yer verilmemiştir.

\section{Ders Kitabı ile Çalışma Kitabının Karşılaştırıımasına Yönelik Bulgular ve Yorum}

Ders kitabındaki okuma ve dinleme metinlerinin söz varlığı unsurları ile öğrenci kitabında yer alan söz varlığı unsurları karşılaştırıldığında 161 kelimenin örtüştüğü ve ortak olarak kullanıldığı, diğer unsurların ise çalışma kitabında bulunan etkinliklerde bulunmadığı görülmüştür. Hedef alınan ortak kelime listesi aşağıda gösterilmiştir. Başında “*” işareti olan kelimeler özel isim olarak kullanılmıştır:

"*atatürk, *avanos, *ay, *güneş, *makbule, *peribacası, *türkiye, *yörük, ad, adam, ağaç, ak, akıllı, akşam, al, al-,an, av, ayva, az, baca, basketbol, bayrak, ben, beslenme, biber, bilgi, bilmece, birden, birinci boş, bu yüzden, bülbül, büyük, ceket, cevap, çabuk, çalılık, çanta, çeşit, çınar, çoban, çok, çorap, çömlek, çünkü, dal, de-, deva, dolu, dönme dolap, düşman, düzey, el, elma, er, erken, fark, fıçı, fikir, futbol, gel-, ger-, gereksinim, gezi, git-, giysi, gök, göl, gör-, gövde, gül, gül-,güneşli, güreş, güzel, hata, hayat, hobi, iç, ilkbahar, iyi, kabuk, kalem, kar, kardeş, karga, kaşık, kayalık, kayısı, kazma, kırmızı, kış, kıyı, koru-,koyun,- kök, kurt, kuru, kuvvet, küçük, kürek, limon, lokomotif, marş, mavi,- mutlu, mutlu ol-, mutluluk, müjde, oku-, okul, ol-, oyna-, oyun, öl-, önce, palto, pınar, sabah, sağlık, sahil, salıncak, sarı, sene, sergi, sevin-, sınav, sınıf, soğuk, sonbahar, sonuç, sümbül, sürü, şaka, şampiyon, şaşkın, şifa, tiyatro, top, toprak, tren, turşu, üzül-, üzüm, vagon, vatan, voleybol, yakın, yaklaş-, yarışma, yavaş, yeşil, yıl, yıldız, yok, yuva, yüz, yüz-,yüzücü."

Sadece çalışma kitabında olup ders kitabındaki metinlerde bulunmayan 50 kelime (*türkçe çalışma kitabı, *türkçe ders kitabı, ada, adak, armut, atıkarınca, bez bebek, bot, çarpışan araba, çirkin, çizme, çöp kutusu, dayanışma, dershane, devamlı, dikdörtgen, ek, ekip, elek, endişseli, fidan, ihtiyaç, ilkyaz, incir, kalemtıraş, kar yağışlı, kazak, kel, kere, kiraz, köle, kör, lök, masa tenisi, muz, parçalı bulutlu, pasta, pembe, portakal, rehber, sağanak yağışl, silgi, siyah, tahsil, testi, turuncu, tuzluk, uçkurluk, yağmurlu, yaprak ) ise etkinliklerde alternatif olarak öğrencilere sunulmuştur. 
2. Sınıf Türkçe Ders Kitabındaki Metinlerle Çalışma Kitaplarındaki Etkinliklerin Söz Varlığı Açısından Karşılaştırılması

\section{Sonuç ve Öneriler}

Ders kitabı ve çalışma kitabı söz varlığı unsurları açısından değerlendirildiğinde, her iki kitapta bulunan ortak kelime oranının düşük olduğu görülmektedir. Ders kitabında bulunan 1826'sı farklı olmak üzere 7449 kelimeye karşılık, çalışma kitabında bulunan kelimelerden 210'u farklı olmak üzere 238 kelime, kelime öğretimine yönelik planlamaya alınmıştır. Yani metinlerde görülen kelimelerin ancak \%8,69'u etkinliklerde öğrencilerin karşısına çıkmaktadır. Bu çok düşük bir orandır. Çalışma kitabı etkinlikleri bir planlama dâhilinde oluşturulan kelime listeleri dikkate alınarak düzenlenmediği için kelime öğretimi süreci öğrenci ve öğretmenin inisiyatifine bırakılmıştır. Illkokullarda öğrencilerin kelime hazinelerinin geliştirilmesi ve ortak bir kelime hazinesi oluşturulması açısından bu sakıncalı bir durumdur. Karadağ ve Kurudayıoğlu (2005:3) da “Aynı düzeydeki öğrenciler arasında dil düzeyleri bakımından bir ortaklık kurulması onlara kazandırılacak ortak bir kelime hazinesi ile mümkün olabilir" ifadesi ile öğrencilerde ortak bir kelime hazinesi oluşturulması gerekliliğini vurgulamışlardır. Bu sebeple ders kitabında bulunan metinlerden sınıf seviyelerine uygun elde edilecek kelime listeleri, öğretim yılının başında belirlenip planlamada yer almalı ve öğretmenlerimiz etkinlikleri sınıflarında uygularken ortak kelime listelerini işe koşmalıdır.

Çalışma kitabına dair kelime listesindeki kelime sıklıklarına bakııdığında ise kelimelerin yalnızca 1,13 oranında tekrar ettiği görülmektedir. Yani öğrenci, etkinliklerde bazı kelimeleri ikinci kez görememektedir. Bu durum öğrencinin karşısına çıkan kelimeyi belirli zaman aralığında öğrenip geçmesine yol açmaktadır. Öğrenci ilerleyen etkinliklerde kelimeyle tekrar karşılaşmadığı için kelimeyi zamanla unutabilir hatta farklı kanallarda destekleyici faaliyetlerde bulunulmazsa öğrencinin öğrendiği kelimeler atıl kalabilir. Öğrencinin kelime anlamı unutmaması ve alıcı kelime hazinesine aktarabilmesi için hazırlanan etkinlikler iç içe geçecek şekilde birbiri ile bağlantılı olarak planlanmalı ve tekrar etkinlikleri ile kelime öğretimi desteklenmelidir.

Çalışma kitabında göze çarpan başka bir husus ise etkinliklerde öğrencilerin 73 farklı kelimeyle görseller vasıtasıyla karşılaşmasıdır. Etkinlik yönergelerinde yalnızca kelime görselleri verilmiş ve öğrencilerden kelimelerin adlarını yazmaları istenmiştir. Kelime anlamları üzerinde durulmamıştır. Aslında bu durumun kitabın genelinde, tüm etkinliklere hâkim olduğu söylenebilir. Kelime anlamlarını bilme yerine kelime adlarını ezberlemeye yönelik etkinlik yönergeleri kitapta sık sık karşımıza çıkmaktadır. Bu durum öğrencinin üretici söz varlığındaki kelimelerin kalıcı olmamasına yol açabilir ve dolayısıyla dilin üretici becerilerinden olan konuşma ve yazma becerileri bu olumsuzluktan etkilenebilir Bu yüzden kelimeleri sesletmek ve adını öğretmek yerine kelime anlamı öğrenme stratejileri kazandıracak etkinlikler hazırlanmalı ve bunlar kitaplarda kullanılmalıdır. Ayrıca etkinliklerde kelime anlamları üzerine yoğunlaşılmalıdır. 
Çalışma kitabındaki toplam 252 etkinlikte, yalnızca bir tane deyimin (gözlerini açmak) hedef gösterilmesi ve atasözlerinin ise her iki kitapta da yer almaması, dikkat çeken önemli bir noktadır. Bu durum öğrencilerin söz varlığı unsurlarının geliştirilmesi açısından düşündürücüdür. Aksan (1996:33), atasözlerini toplumun bilgeliğini, deneyimlerini, dünya görüşünü ve anlatım gücünü yansıtan, yüzyıllarca yaşayabilen sözler şeklinde tanımlayarak atasözlerimizin önemine dikkat çekmiştir. Türkçemiz atasözleri ve deyimler açısından çok zengin bir dil olmasına rağmen öğrencilerimiz kitaplarda bu unsurlardan uzak Türkçe etkinlikleri yapmaktadır. Dilin zenginliğini öğrenemeyen öğrenci, bu unsurları soyut kavramlar olarak algılamakta ve yazma/konuşma çalışmalarında anlamına uygun kullanmakta zorlanmaktadır. Deyim ve atasözlerimizin kaderi, anlamları üzerine etkinlikler planlanmadığı için öğretmenlerin ellerine bırakılmaktadır. Çoğu zaman dilimizi zenginleştiren deyim ve atasözleri çalışmalarda kullanılmamakta sadece sözlüklerde bekletilmektedir. Maalesef bu durum çalışma kitabında yer bulamayan deyim ve atasözlerinde de söz konusudur. İlkokullarda planlamaya alınmayan atasözlerinden habersiz öğrencilerimizin ortaokul sınavlarında karşılarına çıkan atasözleri ile ilgili sorularda başarı oranlarının düşük olması kaçınılmazdır. Bu sebeple öğrenci seviyelerine uygun deyim ve atasözleri tespit edilerek çalışma kitapları etkinliklerinde hak ettiği yeri almalı ve öğrencilere kültürümüzün yadsınamayacak bir parçası olan deyim ve atasözlerimiz kitaplarda sevdirilmeli ve fark ettirilmelidir.

Araştırmada kitaplarda yer alan bulgular, genel olarak değerlendirildiğinde çalışma kitabında yalnızca 161 kelimenin ortak olarak hedef alındığı ve diğer unsurların ise çalışma kitabında yer almadığı görülmektedir. Ders ve çalışma kitabında yer alan söz varlığı unsurları karşılaştırıldığında, kelime öğretimi sürecinin belli bir ölçüte göre değil etkinliklere rastgele serpiştirilerek yapıldığı anlaşılmaktadır. Bu durum Baş ve Karadă̆’ın, (2012:100) “Ülkemizde eğitim ortamında kullanılan ders ve çalışma kitaplarının, hangi söz varlığı listelerine uygun hazırlanacağına dair bir ölçüt bulunmamaktadır" görüşünü doğrular niteliktedir.

Ayrıca çalışma kitabında söz varlığını geliştirici etkinliklerin yeterli olmadığı görülmekte ve Türkçe Öğretim Programında yer alan söz varlığını geliştirme amacının göz ardı edildiği anlaşımaktadır. Eğitim materyallerinin yeterli olmadı̆̆ı yerlerde, ders ve çalışma kitaplarının önemi daha da artmaktadır. Birçok öğretmen, öğretimde neredeyse tüm öğretim sürecini ders kitaplarına yüklemekte ve bunlar dışına çıkmamaktadır. Öğrencilerin söz varlığı unsurlarını geliştirme çalışmalarına da bu olumsuzluk yansımaktadır. Öğretmenler, bu konuda bilinçli olmalı, çalışma kitaplarında var olan etkinlikler ile yetinmeyip gözlemlerine, tecrübelerine ve intiyaca dayalı olarak yeni etkinlikler geliştirmelidir. Oluşturduğu etkinlikler ile öğrencilerin dikkatini çekmeli; soğuk, sıradan ve durağan etkinlikler yerine dinamik, tüm derslere yayılan kelime öğretimine önem vermelidir. Kelime öğretimi geçici bir görev gibi algılanmayıp öğrencilere strateji kazandırma amaçıı olmalıdır. Kelimelerin yanında 
2. Sınıf Türkçe Ders Kitabındaki Metinlerle Çalışma Kitaplarındaki Etkinliklerin Söz Varlığı Açısından Karşılaştırılması

diğer söz varlığı unsurları da dikkate alınarak öğrencilere zengin bir dil kazandırma hedefi oluşturulmalıdır.

\section{Kaynakça}

Aksan, D. (1996).Türkçenin sözvarlığı. Ankara: Engin Yayınevi.

Baş, B. (2006). 1985-2005 yılları arasında çocuk edebiyatı sahasında yazılmış tahkiyeli metinlerin söz varlığı üzerine bir araştırma. Ankara: Gazi Üniversitesi, Eğitim Bilimleri Enstitüsü, Yayımlanmamış Doktora Tezi.

Baş, B. ve Karadağ, Ö. (2012). Söz varlığı üzerine yurt dışında ve Türkiye'de yapılan temel araştırmalar. Millî Eğitim, 193, 81-105.

Karadağ, Ö. (2013). Kelime öğretimi. İstanbul: Kriter Yayınevi.

Karadağ, Ö. ve Maden, S. (2014). Yazma eğitimi: kuram, uygulama, ölçme ve değerlendirme. A. Güzel ve H. Karatay (Ed.), Türkçe öğretimi el kitabı. Ankara: Pegem Akademi.

Karadağ, Ö.ve Kurudayıoğlu, M. (2010). 2005 Türkçe programına göre hazırlanmış ilköğretim birinci kademe Türkçe ders kitaplarının kelime hazinesi. Türklük Bilimi Araştırmaları. 27, 423-436.

MEB. (2006). Illköğretim Türkçe dersi (6, 7, 8. sınıflar) öğretim programı. Ankara: Devlet Kitapları Basımevi.

MEB. (2005). Illköğretim Türkçe dersi öğretim programı ve kılavuzu (1-5. Sınıflar). Ankara: Devlet Kitapları Basımevi.

Onan, B. (2013). Dil eğitiminin temel kavramları. Ankara: Nobel Yayın Dağıtım.

Öz, E. ve Öz, S. (2013). Illköğretim 2. sınıf Türkçe ders kitabı. Ankara: Bilim Kültür Yayınları.

Özdoğru, N. ( 1958). Türkçemiz. İstanbul: Gün Matbaası.

Türk Dil Kurumu. (2005). Türkçe sözlük. Ankara: TDK Yayınları.

Yıldırım, A. ve Şimşek, H. (2013). Sosyal bilimlerde nitel araştırma yöntemleri. Ankara: Seçkin Yayıncilık. 


\section{Ek-1: Ders Kitabında Yer Alan Kelimeler (Sıklık Sırası)}

bir 199, da(de) 134, bu 119, o 103, ol- 101 , çocuk 84 , de- 82 , gel- 74 , çok 63 , ne 59, için 57 , ve 51 , biz 48 , başla47, yap- 47 , anne 46 , sonra 46 , ben(zamir) 44, gün 44, mı(mi mu mü) 44, okul 42, gör- 41, iste- 38, yer 38 , küçük 37 , siz 36 , var 36 , bak- 35, el(organ) 35, al- 34, güzel 33, sen 32, oku- 31, arkadaş 30, git- 30, gibi 28, öğretmen 28 , daha 27 , ver- 27 , yan 26 , anlat- 25 , diye 25 , köy 25 , zaman 25 , iki 24 , kendi 24 , ağaç 23 , her 23 , su 23 , çık- 22 , koş-(koşu) 22, büyük 21, ver 20, ad(isim) 19, oyna- 19, önce 19, *mustafa 19, ama 18, hemen 18 , insan 18 , iyi 18 , söyle- 18, artık 17, at- 17, değil 17, en 17, kadar 17, baba 16, bil- 16, biri 16, çalış- 16, çoban 16, dur- 16, hep 16 , ile 16 , ki 16 , spor 16 , bana 15 , gece 15 , sor- 15 , söz 15 , şu 15 , yok 15 , yol 15 , *atatürk 15 , adam 14 , çiçek 14 , ev 14 , göz 14, in- 14 , izci 14, kuş 14, *afacan 14 , alt 13 , bekle- 13 , doğru 13 , nasıl 13 , neden 13 , şey 13 , aç- 12 , aşağı 12 , dön- 12 , düşün- 12 , gir- 12 , içinde 12 , işte 12 , kız 12 , otur- 12 , oyun 12 , ses 12 , tiyatro 12 , *ali 12 , *berk 12 , ayak 11 , bil 11 , birkaç 11 , birlikte 11 , bul- 11 , dinle- 11 , duy- 11 , güneş 11 , hem 11 , herkes 11 , iş 11 , izcilik 11 , kitap 11, köylü 11, kur-11, sıra 11, üzeri 11, yaşlı(ihtiyar) 11, yat- 11, ara 10, başka 10, bayram 10, bilgi 10, birden 10 , böyle 10 , bugün 10 , ders 10 , elma 10 , hiç 10 , ışık 10 , iç 10 , saat 10 , sanki 10 , tek 10 , yaş(ömür) 10 , yazmak(nesir) 10, yeni 10, yine 10, yüz(çehre) 10, *arda 10, *ay 10, *heidi 10, anla- 9 , baş 9 , birçok 9 , dağ 9 , dal(branş) 9, geç- 9, kar 9, karşı 9, masal 9, sabah 9, sev- 9, tren 9, yapıl- 9, yemek(işi) 9, yıl 9, *sinan 9, *uludağ 9 , bırak- 8 , biraz 8 , bura 8 , burada 8 , çıkar- 8 , fakat 8 , futbol 8 , getir- 8 , göster- 8 , gülümse- 8 , katıl- 8 , kim 8 , kişi 8 , konuş- 8 , kozalak 8 , mavi 8 , oğul 8 , öp 8 , rüya 8 , sağlıklı 8 , seslen- 8 , sevgi 8 , sevin- 8 , sevinç 8 , süt 8 , tane 8 , top 8 , toprak 8 , yaklaş- $8,{ }^{*}$ ekin $8,{ }^{*}$ evliya çelebi 8 , * peter 8 , aynı 7 , bağır- 7 , birbiri 7 , bit-(tükenmek) 7 , bütün 7 , büyü- 7, büyük baba 7, can 7, çalışma 7 , çevre 7 , haber 7 , hava 7 , haydi 7 , hâl 7, kahvaltı 7, kart(kağıt) 7 , keçi 7 , kutla- 7, millet 7, neşe 7, öğren- 7, öyle 7, peki 7, resim 7, son 7, şaşır- 7, tarla 7, tepe 7, topla- 7, unut- 7, ülke 7, üzül- 7, yarış 7, yaşa- 7, yıka- 7, yüz- 7, *ayşegül 7, *karagöz 7, *mehmet âkif 7, *onur 7, *salih efe 7, akşam 6 , amca 6 , arka 6 , beslenme 6 , bile 6 , bilin- 6 , bin- 6 , bulun- 6 , bulut 6 , cep 6 , çiftlik 6 , dal(ağaç) 6 , deniz 6 , dile- 6 , düş- 6 , düşman 6 , gazete 6 , gez- 6 , giysi 6 , gol 6 , gösteri 6 , gül- 6 , halk 6 , hazırlık 6 , hepsi 6 , iç- 6 , izle- 6 , kamp 6 , kardeş 6, karga 6, kırmızı 6, kış(mevsim) 6, kurt(köpek) 6, on 6, ön 6, salıncak 6, sana 6, seç- 6, sevgili 6, sık- 6, tebrik kartı 6, üst 6, yaz 6, ye- 6, *mustafa kemal 6, *zeynep 6, akıl 5, ancak 5, ay 5, balkon 5, bayrak 5, benze- 5, bilmece 5 , birinci 5 , bitir- 5 , bundan 5 , bu kadar 5 , cevap 5 , çağ 5 , çevir- 5 , çünkü 5 , davranış 5 , dışarı 5 , diğer 5 , dolaş- 5 , dolu 5, dört 5, durak 5, durum 5, dünya 5 , eğer 5 , eğlen- 5 , ekmek 5 , eser 5 , eşsiz 5 , genç 5 , giy- 5 , gökyüzü 5 , götür- 5 , güzellik 5 , heyecan 5 , horoz 5 , inan- 5 , kafes 5 , kal- 5 , kalabalık 5 , kat 5 , kaynak 5 , kez 5 , kimse 5 , koy- 5 , mahalle 5 , nerede 5 , olay 5 , ora 5 , otobüs 5 , öğrenci 5 , park 5 , sallan- 5 , sat- 5 , sıkıl- 5 , sınıf 5 , sincap 5 , şiir 5, şimdi 5, tam 5 , tırman- 5 , tilki 5 , tut- 5 , türlü 5 , uç- 5 , uçak 5 , uyu- 5 , yağmur 5 , yalnız 5 , yatak 5 , ya(bağlaç) 5, yürü- 5, *mehmet 5, *türk 5, *türkiye 5, *ürgüp 5, açıl- 4, aile 4, alay et- 4, asker 4, ateş 4, bahçe 4, beğenil- 4, bir an 4, bir daha 4, cumartesi 4, çabuk 4, çanta 4, çek- 4, çınar 4, dayı 4, dost 4, geçir- 4, gerek- 4, göre 4, günaydın 4, hangi 4, hareket 4, hayat 4, hayvan 4, hazırla- 4, her gün 4, hoşlan- 4, ilke 4, ise 4, kabuk 4, karşıla- 4, kaydırak 4, kır(yer) 4, kıyı 4, konak 4, kork- 4, kuru 4, merak 4, meyve 4, otlak 4, önemli 4, önlük 4, örgüt 4, öykü 4, palto 4, pencere 4, sarı 4, sergi 4, sıcak 4, sun- 4, şarkı 4, şekil 4, tanı- 4, taraf 4, taş 4, tatil 4, tatlı 4, teleferik 4, temiz 4, teşekkür et- 4, teyze 4, toplan- 4, turşu 4, tüm 4, uzun 4, üç 4, üşü- 4, var- 4, vur- 4, yakala- 4, yan- 4, yardım et- 4, yarışma 4, yavrum 4, ya da 4, yemek(aş) 4, yiyecek 4, yolcu 4, yorul-(sıkıntı) 4, yön 4, yukarı 4, yurt 4, yüksel4, yüzücü 4, *can 4, *hüseyin bey 4, *kapadokya 4, *makbule 4, *selanik 4, *sibel 4, *şenlikköy 4, abla 3, acaba 3 , ağabey 3 , ağır ağır 3, ak- 3, alın- 3, alış- 3, araba 3, askerî 3, atla- 3 , az 3, bakla 3, barış 3, baston 3, bazen 3 , beri 3 , beş 3 , beyaz 3 , bir ara 3 , boyun 3 , böylece 3 , buluş- 3 , buyur- 3 , buz 3 , canlı 3 , cansız 3 , coşku 3 , çadır 3 , çal- 3 , çıkart- 3, çırpın- 3, dakika 3, değnek 3, dekor 3, denil- 3, dil(lisan) 3, dönem 3, duygu 3, enerji 3, ertesi 3, evlat 3, fark 3, fazla 3, fıçı 3, fırça 3, gövde 3, güzelce 3, hadi(ünlem) 3, haklı 3, her biri 3, her zaman 3, hobi 3, ilan 3, ilgi 3, ilk 3, iyice 3, kafa 3, kahraman 3, kalk-3, kapat- 3, kapı 3, karar 3, karar- 3, kavuş- 3, kaya 3, kazandır- 3, kelime 3, kenar 3, kent 3, kok- 3, kol 3, konmak(kuş) 3, konu 3, kovala- 3, koyun(hayvan) 3, kötü 3, kulübe 3, kural 3, kurul- 3, küçücük 3, lira 3, lokomotif 3, merdiven 3, mutlu ol- 3, nereye 3, otlat- 3, oynan- 3, oyuncak 3, ödül 3, öğrenim 3 , peribacası 3 , pınar 3 , protein 3 , rüzgâr 3 , sabun 3 , saç 3 , sadece 3 , sarıl- 3 , savaş- 3 , sevdik 3 , sevindir3 , seyret- 3 , soğuk 3 , sokak 3 , sonuç 3 , soru 3 , söylen- 3 , söz et 3 , süre 3 , sürekli 3 , sürü 3 , şaka 3 , şampiyon 3 , şeftali 3, şöyle 3, takım 3, tamam 3, torba 3, trafik 3, tuvalet 3, tüket- 3, tür 3, ulaş- 3, utan- 3, uyan- 3, uyku saati 3, uzak 3, uzan- 3, ünlü 3, veril- 3, veya 3, yağ- 3, yakın 3, yak-(ateş) 3, yol boyunca 3, yürek 3, *âkif 3, *barış 3, *bursa 3, *emine 3, *kaymaklı 3, *meclis 3, millî eğitim bakanı 3, *peribacası 3, aç 2, açık 2, aferin 2, ağız 2, ak 2, alacakaranlık 2, alışkanlık 2, alkışla- 2, altı 2, an 2, an- 2, ara- 2, art 2, art- 2, as- 2, asla 2, aslında 2, avuç 2, ayran 2, ayrıl- 2, bağlı 2, bakış 2, bakraç 2, bal 2, balık 2, balo 2, başarılı 2, başkomutan 2, bebek 2, belirle- 2, belki 2, belli 2 , beslen- 2 , beş yüz 2 , bez 2 , bin 2 , binlerce 2 , birdenbire 2 , birleştir- 2 , bol bol 2, boş 2 , boyalı 2 , boy(uzunluk) 2 , bölge 2, burcu burcu 2, bu yüzden 2, ceket 2, coş- 2, çağır- 2, çağrı 2, çalılık 2, çatı 2, çekirdek 2, çimen 2, çubuk 2, dağıt- 2, dal- 2, damlacık 2, davet et- 2, davran- 2, değer 2, dene- 2, devam et- 2, dış 2, dil(organ) 2, dip 2, doğ2 , doy- 2 , doya doya 2 , dönüş 2 , dönüş- 2 , döşen- 2 , dua 2 , durmadan 2 , dün 2 , edin- 2 , elbette 2 , endişe 2 , erken 


\section{Sınıf Türkçe Ders Kitabındaki Metinlerle Çalışma Kitaplarındaki Etkinliklerin Söz Varlığı Açısından Karşılaştırılması}

2, er(erkek) 2, eski 2, et 2, et- 2, farklı 2, fetih 2, fırla- 2, fikir 2, geçen 2, gerçekten 2, geril- 2, gök 2, göl 2, görün2 , grup 2 , güzel güzel 2 , hafif 2 , hafta sonu 2 , hamburger 2 , hangisi 2 , hasta 2 , hatırla- 2 , havuz 2 , hazırlan- 2 , hazine 2, hâlâ 2, hele 2, heyecanlı 2, hızla 2, hiçbir 2, hisset- 2, hoş 2, ısın- 2, ışıl ışıl 2, i- 2, içeri 2, ihtiyar 2, ileri 2, ilerle- 2, ilgili 2, ipucu 2, isim 2, istek 2, işit- 2, izin 2, kabul et- 2, kaç 2, kadife 2, kaldır- 2, kalem 2, kalp 2, kapkara 2, kaput bezi 2, kara yolu 2, karlı 2, karşıık 2, kasım 2, kaşık 2, kat- 2, kay- 2, kaybol- 2, kaymak(sürtünmek) 2, kazan- 2, kâse 2, kesil- 2, kır- 2, kıyafet 2, kızar- 2, kimsesiz 2, kirli 2, kişilik 2, kocaman 2, koca(büyük) 2, koku 2, kolay 2, koro 2, koruluk 2, kucaklaş- 2, kulak 2, kullan- 2, kurtar- 2, kutu 2, kuvvet 2, lavabo 2, limon 2, lunapark 2, mandalina 2, mart 2, matematik 2, mermer 2, meyve suyu 2, mırıldan- 2, minik 2, mutlaka 2, mutlu et- 2, nefes 2, neşeli 2, niçin 2, oda 2, okşa- 2, oluş- 2, orman 2, ortalık 2, ova 2, öl- 2, öt- 2, öyleyse 2, özellikle 2, özen- 2 , padişah 2, para 2, parla- 2, paşa 2, paylaş- 2, pazar 2, peynir 2, piş- 2, rica et- 2, rol 2, sağla- 2 , sahip 2 , sahne 2 , sakallı 2 , sakin 2 , saldır- 2 , salla- 2 , salon 2 , sarp 2 , saygı 2 , sayı 2 , sene 2 , servis 2 , set 2 , sevil- 2 , seyahat 2 , sıralan2 , soy- 2 , sür- 2 , şehir 2 , şeker 2 , şirin 2 , tabii 2 , tak- 2 , takıl- 2 , tanış- 2 , taşıt 2 , tat 2 , tavuk 2 , teneke 2 , titre- 2 , tl 2, toparla- 2, tören 2, tutsaklık 2, türkü 2, uçurum 2, uy- 2, uygun 2, uza- 2, uzat- 2, ürün 2, üzere 2, üzüntü 2, vadi 2 , vahşi hayvan 2 , vakit 2, var gücü 2, vatan 2, yamaç 2, yaramazlık 2, yarar 2, yararlan- 2, yararlı 2, yardım iste2 , yarım 2, yavaşça 2, yavaş yavaş 2, yayıl- 2, yayla 2, yazı(nesir) 2, yedi 2, yeni yeni 2, yenmek(galip) 2, yerleştir2, yıldız 2, yılsonu 2, *yörük 2, yuva 2, yüksek 2, zayıf 2, zekâ 2, zil 2, zorluk 2, *ahmet 2, *alm yamaçları 2, *anadolu 2, *ankara 2, *derinkuyu 2, *erpınarı 2, *göreme 2, *günseli öğretmen 2, *hacivat 2, *ıhlara vadisi 2, *ingiliz 2, *istanbul 2, *istiklâl marşı 2, *izmir 2, *kâmil bey 2, *kemal paşa 2, *serpil hanım 2, *seyahatname 2, *vali kâzım dirik 2, a 1, acele et- 1 , acı 1, açılış 1 , adaş 1 , adım 1, adım adım 1 , adlı 1 , ağaçlı 1 , ağır 1 , ağırlaş- 1 , ağla- 1 , ağlat- 1 , ağustos böceği 1 , ahali 1 , akıllı 1 , akma 1 , akran 1 , aksat- 1 , akşamüstü 1 , al 1 , alabil- 1 , alan 1 , alçal- 1 , alkış 1 , alt et- 1 , alt yan 1 , amaç 1 , aman 1 , amin alayı 1 , anı 1 , anlam 1 , anlaşıl- 1 , anlatabil- 1 , anlı şanlı 1 , araç 1, arada 1, arada bir 1, araştırma 1, araştırmacı 1, ara sıra 1, ardınca 1, armağan et- 1 , arttır- 1 , arzu 1 , asansör 1 , asıl- 1 , asılı 1, at 1, atan- 1 , atıl- 1 , atletizm 1 , atlıkarınca 1 , av 1 , ayak uydur- 1 , aydın 1 , aydınlat- 1 , aydınlık 1 , ayı 1 , ayna 1 , ayrı 1 , ayrı ayrı 1 , ayva 1 , ay yıldız 1, b 1 , baca 1 , badanalı 1 , bağ 1 , bağlan- 1 , bağrış- 1 , baklagiller 1 , bardak 1 , bas- 1 , basar basmaz 1 , basbayağı 1 , basılı 1 , basketbol 1 , başarı 1 , başıboş 1 , başucu 1 , başvur- 1 , başvuru 1 , bayıl- 1 , baykuş 1 , bazı 1 , becerikli 1 , beden 1 , beden eğitimi 1 , beğen- 1 , bekleyiş 1 , belediye 1 , bembeyaz 1 , bence 1 , benzer 1 , benzersiz 1 , beraber 1 , bereketli 1 , besin 1 , beşer 1 , biber 1 , bildiril- 1 , bilek 1 , bilgilendir- 1, bilgili 1, binbaşı 1, bindir- 1, biner binmez 1, bin altı yüz on bir 1, bin dokuz yüz yirmi 1, bin dokuz yüz yirmi bir 1, bin sekiz yüz seksen bir 1, birer 1, bireysel 1, birlik 1, bir anda 1, bir avuç 1, bitiver-(tükenmek) 1 , bocala- 1 , bol 1 , boşal- 1 , boya 1 , boya- 1 , boylu boyunca 1 , boyunca 1 , börek 1 , böylesine 1 , budak 1 , buğday 1 , buhar 1 , buharlaş- 1 , buharlaşıver- 1 , bulabil- 1 , bundan böyle 1 , bük- 1 , bülbül 1 , c 1 , cami 1 , cankurtaran 1 , canlandır- 1 , centilmenlik 1 , cephe 1 , cesaret 1 , cesur 1 , ceviz 1 , cilt 1 , cirit 1 , civar 1 , cumhuriyet 1 , çabucak 1 , çakıl 1 , çakıllı 1 , çalım 1 , çalışan 1 , çalışkan 1 , çam 1 , çan 1 , çarçabuk 1 , çarp- 1 , çarpışan 1 , çarşaf 1 , çarşı 1 , çatlak 1 , çayır 1 , çelik 1 , çember 1 , çeşit 1 , çevril- 1 , çevrili 1 , çeyrek 1 , çıkagel- 1 , çıkarıl- 1 , çıkış 1 , çıt(ünlem) 1 , çiçekli 1 , çift 1 , çifte kavrul- 1 , çift çubuk 1 , çikolata 1 , çocukluk 1 , çoğu 1 , çoluk çocuk 1 , çorap 1 , çorba 1 , çömlek 1 , çöp 1, çörek 1, çözül- 1, dağarcık 1, dağılım 1, dağıtım 1, damla 1, dans et- 1 , dar(ensiz) 1, dayan- 1, dayanama- 1 , dayana dayana 1 , dede 1 , defter 1 , değdir- 1 , değin- 1 , değiş- 1 , dek 1 , del- 1 , demet 1 , demir 1 , dere 1 , dergi 1 , deri 1 , derin 1 , derin derin 1 , dertli 1 , der demez 1 , deva 1 , devrim 1 , dik 1 , dikiver- 1 , dilenci 1 , disiplinli 1 , diş 1 , diyebil- 1 , dizi dizi 1, doğra- 1 , doğum 1 , dokun- 1 , dol- 1 , doyum 1 , doyur- 1 , dök-1, dökül- 1, dökülüver- 1 , dönme dolap 1, dudak 1, duru 1, duvar 1 , duygulandır- 1 , duyur- 1 , duyuru 1 , düdük 1 , dürüst 1 , düş 1 , düşünce 1 , düzeltme 1 , düzenli 1 , düzey 1 , düzgünleş- 1 , eğ- 1 , eğil- 1 , eğit- 1 , eğitim 1 , eğlenceli 1 , eğlendir- 1 , eğlendirici 1 , ek- 1 , ekle- 1 , ekli 1 , el 1 , elektrik 1 , eli sopalı 1 , el birliği 1 , el sanatları 1 , emanet et- 1 , emir 1 , epeyce 1 , erik 1 , erkek 1 , etek 1 , ey 1 , falan 1 , falso 1 , fanila 1 , farkında ol- 1 , farklılaş- 1 , fener 1 , fıçıcık 1 , fındık 1 , fırçala- 1 , fısıltı 1 , fıstık 1, fışkır- 1, fren 1, futbolcu 1, gagala- 1 , gayret 1 , geciktir- 1 , geçim sıkıntısı 1 , geçin- 1 , geçiver- 1 , geçmiş 1 , gelecek 1 , gelenek 1 , geliş- 1 , gemici 1 , gençlik 1 , genişlet- 1 , ger- 1 , gereksinim 1 , geri 1 , geriye 1 , geri çekil- 1 , geyik 1 , gezi 1 , gezinti 1 , gidebil- 1 , gider- 1 , giriş 1 , gittikçe 1 , gölge 1 , gönül 1 , gönüllü 1 , görev 1 , görül- 1 , görüntü 1 , görünüm 1 , görünür 1 , görüş 1 , gözleme(işi) 1 , gözyaşı 1 , göz göze 1 , güçlü 1 , güç(kuvvet) 1 , gül 1 , gündüz 1 , güneşli 1 , gürbüz 1 , güreş 1 , gürültü 1 , güvenilir 1 , hak 1 , hakem 1 , hakkında 1 , hak(adalet) 1 , hal 1 , halı 1 , halkoyunu 1 , hani 1 , hareketsiz 1 , hareket et- 1 , harıl harıl 1 , harika 1 , hastane 1 , hata 1 , hatırlat- 1 , hatta 1 , havalandırma 1 , havuç 1 , hayal 1 , hayır 1 , haykır- 1 , hayrola 1 , hazır 1 , hazırlıklı 1 , hediye 1 , henüz 1 , heyecanlan1 , heyecanlandır- 1 , hey(ünlem) 1 , hızlı hızlı 1, hiçbiri 1, hizmet et- 1 , homurtu 1 , hopla- 1 , hoşçakal 1 , hoşgörü 1 , hücum 1, Isır- 1, Islan- 1, Işıt- 1 , içten 1, ihtiyarca 1, ikinci 1, ikna et- 1 , ilet- 1 , ilgilen- 1 , ilişki 1, ilkbahar 1 , ilkokul 1 , ilköğretim 1 , iman 1 , imdat 1 , incele- 1 , ince yapılı 1 , inci 1 , incit- 1 , inci çiçeği 1 , inle- 1 , inlet- 1 , inşallah 1 , iri 1 , istop 1 , işaret 1 , it- 1 , iyilik 1 , iz 1 , izlenim 1 , izleyici 1 , jimnastik 1 , kabak 1 , kablo 1 , kabuklu 1 , kaç- 1 , kadın 1 , kahkaha 1, kalaylı 1, kalın 1, kalın ses 1 , kalkındır- 1, kamyon 1, kanat 1, kana kana 1, kanı 1, kantin 1, kapan- 1 , kapkaranlık 1, kapla- 1, kaplı 1, kaptır-1, kara kuru 1, kara(renk) 1, kardeşçe 1, kardeşlik 1, karın 1, karış- 1, karne 1, kartal 1, kasaba 1, kast et-1, kavur-1, kayak 1, kayalık 1, kaybet-1, kayboluver-1, kaydedil- 1, kaydol- 1, kayg । 
1, kayısı 1, kaymak(süt) 1, kayna- 1, kaynaştır- 1, kazma 1, kekik 1, kelebek 1, kes- 1, kesiliver- 1, kestir- 1, keyifli 1 , kına 1, kıpırtı 1, kıpkırmızı 1, kırgın 1, kısa 1, kısaca 1, kısık 1, kıs kıs 1, kızart- 1, kızılcık 1, kibar 1, kilise 1, kokulu 1 , komutan 1, kontrol 1, kopar- 1, kor- 1 , koridor 1 , korku 1, korkut- 1, koru- 1, korun- 1, kov- 1, koyul- 1, köfte 1 , kök(bitki) 1, köpük 1, köşe 1, kötülük et- 1, kucak 1, kulaç 1, kumandan 1, kurak 1, kurs 1, kurşun kalem 1, kurtul1 , kuru- 1, kurucu 1, kurutul- 1, kus- 1 , kuşak 1, kutsal 1, küçük bey 1 , küçük hanım 1, küme 1, küpe 1, kürek 1 , küs 1 , kütle 1 , küt küt 1 , ladin 1 , lahana 1 , lamba 1 , lazım 1 , liste 1 , lütfen 1 , maç 1 , madalya 1 , maddi 1 , mağara 1, mahalle arkadaşı 1 , mahcup ol- 1 , maket 1 , malzeme 1 , marş 1 , masa 1 , masalcı 1 , masmavi 1 , matematikçi 1 , mavilik 1, maymun 1 , meğer 1 , memleket 1 , menekşe 1 , menü 1 , merak et- 1 , mertçe 1 , metre 1 , meyveli 1 , mezar 1, mışı mışı 1, millî 1, modern 1, motorlu 1 , musluk 1, mutlu 1, mutluluk 1 , müjde 1 , müjdeci 1, mükemmel 1 , mümkün 1 , müzik 1 , nazik 1 , nefis(çok güzel) 1 , neresi 1 , nergis 1 , nesil 1 , nihayet 1 , nisan 1 , niye 1 , niyet 1 , not 1 , nöbet 1 , odun 1 , oflayıp pufla- 1 , oksijen 1 , okur 1 , okut- 1 , olanaksız 1 , olgun 1 , oluk 1 , oluştur- 1 , omuz omuza 1 , onur 1 , on dokuz 1 , on iki 1 , on ikinci 1 , on para 1 , oralı 1 , ordu 1 , orta 1 , ovuştur- 1 , oyalanmak(meşgul) 1 , oyalanma(meşgul) 1, oyala-(meşgul) 1 , oyuk 1 , oyuncu 1 , öbür 1 , ödünç 1 , öfkelen- 1 , öğle 1 , öğle tatili 1 , öğle yemeği 1 , öğret- 1 , öğüt 1 , önem 1 , öner- 1 , önlen- 1 , öpüş- 1 , ör- 1 , örgülü 1 , örtü 1 , öte 1 , öttür- 1 , övün- 1 , özle1, özür dile- 1, pabuç 1, *kanuni 1, paket 1, parasız 1, parça 1, parlayıver-1, pas(futbol) 1, pazartesi 1, pembe pembe 1 , peş 1 , peygamber 1 , pınar başı 1 , pırasa 1 , piknik 1 , piknik yeri 1 , pişir- 1 , pişman ol- 1 , piyes 1 , polis 1 , postala- 1 , radyo 1 , raf 1 , rakip 1 , ray 1 , rehberlik 1 , rengârenk 1 , renk 1 , renkli 1 , resimli 1 , resmi 1 , sabır 1 , sabırsızlan- 1, sabırsızlık 1, saçıl- 1, saçlı 1, sağ- 1, sağlık 1, sağ(yön) 1, sahil 1, sakın 1, sakin ol- 1 , sakin sakin 1 , saklan- 1 , sal- 1 , salıver- 1 , salyangoz 1 , sarhoş ol- 1 , savaş 1 , savrul- 1 , savun- 1 , saygılı 1 , sayıkla- 1 , sayma 1 , sebze 1 , seçil- 1 , sefer 1 , sekiz 1 , selam 1 , sembol 1 , sepet 1 , sergile- 1 , sert 1 , serüven 1 , sessiz 1 , sevimli 1 , sevindirici 1, sıcacık 1, sıçra- 1, sıkı 1, sıkıntı 1, sıkışıklık 1, sık sık 1, sınav 1, sıra sıra 1, sırt 1, sıvazla- 1, sıvı 1, silkin1 , siren 1 , sis 1 , sistem 1 , sistemli 1 , soğu- 1 , soğuyuver- 1 , sohbet 1 , sok- 1 , soluk soluğa 1 , sol(yön) 1 , sonbahar 1 , son derece 1 , sorun 1 , soruştur- 1 , sön- 1 , sporcu 1 , subay 1 , sulak 1 , susa- 1 , sümbül 1 , sürü- 1 , sürül- 1 , sürüye kat- 1 , süsle- 1 , süslü 1 , süzül- 1 , şair 1 , şakalaş- 1 , şan 1 , şapka 1 , şaşırt- 1 , şaşırtıcı 1 , şaşkın 1 , şehirli 1 , şerbet 1 , şırıl şırı 1, şifa 1, şikâyet et- 1 , şoför 1 , tabak 1, tahıl 1, tahta 1, takla 1, taklit 1, tamamlan- 1, tandır ekmeği 1 , tara- 1 , tarih 1 , taşın- 1 , taşlı 1 , tatlı dilli 1 , taze 1 , tazı 1 , tebrik 1 , tedirgin 1 , tehlike 1 , tek başına 1 , tel 1 , telaş 1 , telefon 1 , televizyon 1 , terbiye 1 , tereyağı 1 , tertemiz 1 , testi kebabı 1 , teşkilat 1 , tıkan- 1 , tıpkı 1 , tırmanış 1 , tiz 1 , tomurcuk 1 , tur 1 , turistik 1 , turşucuk 1 , tuttur- 1 , tutul- 1 , tutumlu 1 , tuz 1 , tüken- 1 , tükenmez 1 , uçan 1 , uçur1, uçurtma 1, uçuşa döne 1, ufacık 1, um- 1, unutul- 1, unutuver- 1 , usul(yavaş) 1, utanç 1, uyandır- 1 , uyanık 1 , uydur- 1 , uyku 1 , uykuya dal- 1 , uyul- 1 , uyuya kal- 1 , uzaklaş- 1 , uzaklık 1 , üfle- 1 , ün 1 , üniversite 1 , ürkek 1 , üstelik 1, üstün(galip) 1, ütü 1, üzgün üzgün 1, üzüm 1, vagon 1 , vazgeç- 1 , vb 1, vın vın(ünlem) 1 , voleybol 1 , vücut 1 , yağlı 1, yaka 1 , yakan top 1 , yakıcı 1, yakınlık 1 , yalan 1 , yalancı 1 , yalnızlık 1 , yalvar- 1 , yanar yanmaz 1 , yanıtla- 1 , yani 1 , yanlışlık 1, yan yana 1 , yaptır- 1 , yara- 1 , yaraşı 1 , yardım 1 , yardıma koş- 1 , yardımcı ol- 1 , yardımsever 1, yarıl- 1, yarın 1, yarış- 1, yaslan-(dayanmak) 1, yaşam 1, yaşasın 1 , yaşat- 1 , yaşıı(ıslak) 1 , yavaş 1 , yavşan 1 , yaygınlaş- 1 , yayımla- 1 , yazdırıl- 1 , yazı tahtası 1 , yazlık 1 , yedi yüz yirmi dört 1 , yenilik 1 , yeraltı 1 , yerleş- 1 , yerleşim 1 , yeryüzü 1 , yeşil 1 , yeşil ışık 1 , yet- 1 , yetenek 1 , yeter 1 , yetiş- 1 , yetiştiril- 1 , yirmi beş 1 , yirmi üç 1, yokla- 1, yoklama 1 , yolculuk 1 , yontucu 1 , yorgun 1 , yorucu 1 , yo(ünlem) 1, yönlendir- 1, yöre 1 , yöresel 1 , yumurta 1 , yuvarlaya yuvarlaya 1 , yürüye yürüye 1 , yüzey 1 , yüzyıl 1 , yüz(sayı) 1 , yüz-(suda) 1 , zafer 1 , zahmet etme 1 , zaman zaman 1 , zapt et- 1 , zaten 1 , *zeynep 1 , zıpla- 1 , zıp zıp zıpla- 1 , ziyaret 1 , ziyaret et- 1 , zor 1, zorunluluk 1, *akpınar 1, *akseki 1, *ali rıza efendi 1, *alm 1, *alman 1, *ata 1, *avanos 1, *ayşe 1, *ayvalılar 1, *ayvalı köyü 1, *bademli 1, *baden powell (baden povıl) 1, *barbaros ilköğretim okulu 1, *barışlar 1, *boy scouting (boy skantink) 1, *burcu 1, *cumhuriyet bayramı 1, *çoban çeşmesi 1 , *derebahçe 1 , *dertlipınar 1 , *fahri 1, *fatma 1, *fransızca 1, *gazi 1, *gazi mustafa kemal paşa 1, *gazi paşa 1, *general baden powell 1, * gülsüm nine 1 , *hamit çavuş 1 , *heidi (haydi) 1 , *hüseyin dayı 1 , *ingiltere 1 , *izmir hakimiyet-i milliye ilkokulu 1, *izmir palas 1, *karapınar 1, *kâmil ceylan 1, *keltepe 1, *kemal 1, *kıbrıs 1, *kınalıtepe 1, *kırkpınar 1, *kordon 1 , *kurtuluş savaşı 1, *kütahyalı 1, *marmara denizi 1, *mehmet âkif ersoy 1 , *melendiz çayı 1 , *millî eğitim bakanlığı 1, *mustafa bey 1, *müftüler 1 , *nergislik 1 , *nevşehir 1 , *nilüfer 1 , *oktay 1 , *orta çağ 1 , *pembe panter $1,{ }^{*}$ romalı 1 , *sami 1 , *sinan balaban 1 , *şemsi efendi ilkokulu 1 , *şenlikköylüler 1 , *türkiye büyük millet meclisi başkanı 1, *ulupınar 1, *umut 1, *yanıkpınar 1, *yeni çağ 1, *yeşilköy 1, *zerdalioluk 1, *zübeyde hanım 1. 


\section{Sınıf Türkçe Ders Kitabındaki Metinlerle Çalışma Kitaplarındaki Etkinliklerin Söz Varlığı Açısından Karşılaştırılması}

\section{Ek-2: Çalışma Kitabında Yer Alan Kelimeler (Sıklık Sırası)}

gel- 4, *peribacaları 2, ağaç 2, atlıkarınca 2, az 2, bilmece 2, büyük 2, cevap 2, çok 2, el 2, fıçı 2, gül 2, güzel 2, ilkbahar 2, kaşık 2, kırmızı 2, küçük 2, mavi 2, pembe 2, salıncak 2, sarı 2, şaka 2, top 2, yavaş 2, yüz 2, yüz- 2, *atatürk 1, *avanos $1, *$ ay 1 , *güneş 1 , *makbule 1 , *türkiye 1 , ad 1 , ada 1 , adak 1 , adam 1 , ak 1 , akıllı 1, akşam 1 , al 1 , al- 1 , an 1 , armut 1 , av 1 , ayva 1 , baca 1 , basketbol 1 , bayrak 1 , ben 1 , beslenme 1 , bez bebek 1 , biber 1 , bilgi 1 , birden 1 , birinci 1 , boş 1 , bot 1 , bu yüzden 1 , bülbül 1 , ceket 1 , çabuk 1 , çalılık 1 , çanta 1 , çarpışan araba 1, çeşit 1, çınar 1, çirkin 1, çizme 1, çoban 1, çorap 1, çömlek 1, çöp kutusu 1, çünkü 1, dal 1, dayanışma 1 , de- 1 , dershane 1, deva 1, devamlı 1, dikdörtgen 1, dolu 1, dönme dolap 1, düşman 1 , düzey 1 , ek 1 , ekip 1, elek 1 , elma 1 , endişeli 1 , er 1 , erken 1 , fark 1 , fidan 1 , fikir 1 , futbol 1 , ger- 1 , gereksinim 1 , gezi 1 , git- 1 , giysi 1 , gök 1 , göl 1 , gör- 1 , gövde 1 , gül- 1 , güneşli 1 , güreş 1 , hata 1 , hayat 1 , hobi 1 , iç 1 , ihtiyaç 1 , ilkyaz 1 , incir 1 , iyi 1 , kabuk 1 , kalem 1, kalemtıraş 1 , kar 1 , kar yağışlı 1, kardeş 1 , karga 1, kayalık 1 , kayısı 1, kazak 1, kazma 1, kel 1, kere 1 , kış 1 , kıyı 1, kiraz 1 , koru- 1 , koyun 1 , kök 1 , köle 1 , kör 1 , kurt 1, kuru 1, kuvvet 1 , kürek 1, limon 1, lokomotif 1 , lök 1 , marş 1 , masa tenisi 1 , mutlu 1 , mutlu ol- 1 , mutluluk 1 , muz 1 , müjde 1 , oku- 1 , okul 1 , ol- 1 , oyna- 1 , oyun 1 , öl- 1, önce 1, palto 1, parçalı bulutlu 1, pasta 1, pınar 1, portakal 1, rehber 1 , sabah 1 , sağanak yağışlı 1 , sağlık 1 , sahil 1 , sene 1 , sergi 1 , sevin- 1 , sınav 1 , sınıf 1 , silgi 1 , siyah 1 , soğuk 1 , sonbahar 1 , sonuç 1 , sümbül 1 , sürü 1 , şampiyon 1 , şaşkın 1 , şifa 1 , tahsil 1 , testi 1 , tiyatro 1 , toprak 1 , tren 1 , turşu 1 , turuncu 1 , tuzluk 1 , türkçe çalışma kitabı 1, türkçe ders kitabı 1, uçkurluk 1, üzül- 1, üzüm 1, vagon 1, vatan 1, voleybol 1, yağmurlu 1, yakın 1, yaklaş1 , yaprak 1, yarışma 1, yeşil 1, yıl 1, yıldız 1, yok 1, yörük 1, yuva 1, yüzücü 1.

\section{Ek-3: Ders Kitabında Yer Alan İkilemeler (Sıklık Sırası)}

ağır ağır 3, her biri 3, bol bol 2, burcu burcu 2, doya doya 2, güzel güzel 2, ışıl ışıl 2, yavaş yavaş 2, yeni yeni 2, adım adım 1, anlı şanlı 1, ayrı ayrı 1, basar basmaz 1 , biner binmez 1 , boylu boyunca 1 , bundan böyle 1 , çoluk çocuk 1 , dayana dayana 1 , der demez 1 , derin derin 1 , dizi dizi 1 , göz göze 1 , harıl harıl 1 , hızlı hızlı 1 , kana kana 1 , kara kuru 1, kıs kıs 1 , küt küt 1 , mışı mışı 1 , omuz omuza 1 , pembe pembe 1 , sakin sakin 1 , sık sık 1 , sıra sıra 1, soluk soluğa 1, şırıl şırıl 1, uçuşa döne 1, üzgün üzgün 1, vın vın(ünlem) 1, yan yana 1, yanar yanmaz 1, yuvarlaya yuvarlaya 1 , yürüye yürüye 1 , zaman zaman 1 , zıp zıp 1 .

\section{Ek-4: Ders Kitabında Yer Alan Deyimler (Sıklık Sırası)}

adını vermek 2, ayağa kalkmak 2, dile gelmek 2, haber vermek 2, kendinden geçmek 2, yer vermek 2, yol açmak 2, adam olmak 1, adım atmak 1, adını koymak 1, ağzı kulaklarına varmak 1 , alt etmek 1 , ayak basmak 1 , ayak uydurmak 1 , başından geçmek 1 , canı sıkılmak 1 , can vermek 1 , doyum olmamak 1 , dünyaya gelmek 1 , elinden tutmak 1, eli sopalı (olmak) 1 , farkında olmamak 1 , fark etmek 1 , geri çekilmek 1 , geri çevirmek 1 , gözden geçirmek 1, gözden kaybolmak 1, göze gelmek 1, göz atmak 1, gürültü çıkarmak 1, haklı bulmak 1, haklı çıkmak 1, hoşuna gitmek 1, ipucu vermek 1, işe yaramamak 1, işine gelmek 1, işini bitirmek 1, işini görmek 1, iyi olmak 1 , kestirip atmak 1, kök salmak 1, kulak kesilmek 1, oflayıp puflamak 1, oralı olmamak 1, özür dilemek 1, peşinde koşmak 1, selam vermek 1 , şaka yapmak 1 , tatlı dilli (olmak) 1, tur atmak 1, uykuya dalmak 1 , yerinde duramamak 1 , yerine getirmek 1, yer almak 1, yol almak 1, yol göstermek 1, yol vermek 1. 